Підгорбунський Микола Анатолійович, кандидат історичних наук, доцент, Київський національний університет культури імистецтв

\title{
ПРОБЛЕМИ ТА ПЕРСПЕКТИВИ В ДОСЛДЖЕННЯХ КОНДАКАРНОЇ НОТАЦІї
}

Стаття присвячена кондакарній нотачії, яка була поширена за часів Київської Русі до XIV cm. Проаналізовано наукові праці європейських науковціів присвячених стародавній нотаціï.

Ключові слова: иерковний спів, кондак, стародавня нотація, співочі рукописи.

Статья посвящена кондакарной нотащии, которая была распространена во времена Киевской Руси в XIV в. Проанализированы научные труды европейских ученых посвященных древней нотации.

Ключевые слова: иерковное пение, кондак, древняя нотация, певческие рукописи.

The article is devoted kondakarniy notation that was prevalent at the time of Kievan Rus to the XIV century. Analyzed the scientific work of European scientists dedicated to the ancient notation.

Key words: church singing, kondac, ancient notation, singing manuscripts.

Кондакарний спів є одним зі стародавніх видів церковного співу в Київській Русі. Назва походить від слова «кондак» - одного з найстаріших жанрів християнських піснеспівів. Давні кондаки записували особливою безлінійною нотацією, яку й донині не розшифровано. Над дослідженням кондакарної нотації тривалий час працюють українські та іноземні дослідники. Саме проблемам розшифрування кондакарного нотопису присвячені наукові праці М. Фіндейзена, В. Ундольського,В. Металлова, М. Успенського, І. Гарднера, К. Хьога, Р. Палікарової-Вердель, Т. Владишевської та ін.

Завдання статті - дослідити появу кондакарної нотації в Київській Русі, проаналізувати грунтовні дослідження українських та зарубіжних вчених, які присвятили свої праці розшифруванню кондакарного нотопису; визначити проблеми та перспективи майбутніх досліджень у цьому напрямку.

Кондакарна нотація, на відміну від Стовпової невменної, призначалася для запису обмеженого кола піснеспівів, переважно - кондаків, а також деяких інших видів піснеспівів: іпакоїв, седальнів, кінонніків. Ця нотація записувалася в два рядки, один над одним, під цими рядками був словесний текст. Нижній рядок нотопису становили малі кондакарні знаки, а верхній рядок - великі. Кондакарна нотація подібна до палеовізантійської і характеризується наявністю мелодично розвинутих елементів [12].

На сьогодні збереглося шість слов'янських рукописних книг - Кондакорів. П'ять книг нотовані кондакарними знаками, які є відмінними від Стовпової невменної нотації. Це «Кондакар Друкарського Статуту», який датують кінцем XI - початком XII ст. Свою 
назву отримав від останнього місця зберігання в Друкарській бібліотеці. До нього входять піснеспіви річного святкового кола - мінеї, календарні свята пам'яті святих, кондаки Тріоді і недільні кондаки восьми гласів, а також кондакарні прокімни «Всякое диханіе» на вісім гласів і різноманітні піснеспіви записані невменним нотописом це аллілуарії, кафізми та стихіри. У Кондакарі Друкарського Статуту нотованими є тільки 38 самогласних оригінальних кондака і 5, які виконуються на подобен. Усі інші кондаки, які виконуються на подобен, не нотовані і мають тільки вказівку на самогласний кондак, що є йому зразком. Текст самогласних кондакорів написаний у двох варіантах: перший без нотації, другий - розписаний кондакарним нотописом [8].

Благовіщенський кондакар написано наприкінці XII - початку XIII ст. До нього входять не тільки розспівані кондаки, а й іпакої, полієлеї, азматики, светильні, євангельскі стихіри. Благовіщенський Кондакар, подібно до Типографського, був також нотований кондакарним та невменним нотописом.

Успенський кондакар має точну дату написання 1204 р. Він включає кондаки, тропар і частину служби Різдва Христова, катавасії на господські свята та святим, іпакої, тропарі, недільні піснеспіви із Літургії, кіноніки. Троїцький або Лаврський кондакар написано наприкінці XII - початку XIII ст. До нього входять кондаки, іпакої, тропарі 3 віршами.

Кондакар ОИДР ХІІ ст. - майже ненотований кондакар, одна його частина зберігається в Москві, друга - в Санкт-Петербурзі. Кондакар включає кондаки, ікоси, светильні з богородичними, євангельські стихіри. Цей кондакар мав тільки окремі аркуші, на яких був кондакарний та невменний нотопис.

Синодальний кондакар написано в XIII ст. Цей кондакар має тільки незначний нотований уривок, який датується більш пізнім часом, аніж сам рукопис. До нього входять кондаки, кіноніки, недільний антифон, тропарі на Різдво Христове і на Хрещення.

Окрім зазначених шести кондакорів, у деяких рукописах трапляються окремі частини, нотовані кондакарною нотацією - це кондак в Лазареву суботу і Великодню в Октоїхе ізборному XIII ст., Збірник богослужбовий XIII ст., Мінея августовська. Окремі елементи кондакарного нотопису в деяких місцях з'єднуються із невменною, наприклад у стихірі Борису і Глібу [8].

Дослідник М. Фіндейзен висловлює припущення, що кондакарна нотація була запозичена зі співочої практики грецької церкви. Але вчений також зазначає, що не можна зробити будь-який остаточний висновок про цю зниклу нотацію, поки не буде видання або дослідження більш «повного пам'ятника кондакарной нотації, коли 3’ясувався б повний склад верхніх і нижніх знамен» [21, с. 96].

Датський вчений Карстен Хьог (Carsten Hoeg) вважав, що кондакарна нотація була особливим слов'янським різновидом, де нижній рядок невм відповідав силабічному тексту, а верхній вказував на цілі формули мелізматичного стилю. Дослідник вважав, що нижні рядки в простому вигляді використовували ще античні греки в риторичних творах, а «верхній слугував для позначення музичних особливостей східного мелізматичного співу» [4].

Троїцький Кондакар досліджував В. Ундольський уроботі «Замечания для истории церковного пения в России», яка була надрукована в 1846 р. в альманасі «Чтения 
Общества Истории и Древностей Российских». Автор звертає увагу на те, що в рукописі $\epsilon$ кондак Св. Борису і Глібу. Але головне, порівнюючи цей Кондакар із відомими рукописними книгами (Толстовською, Синодальною та Румянцевською) В. Ундольський вказує на відмінність нотопису Кондакоря від названих. А саме, що нотні знаки Троїцького кондакаря відмінні від нотних знаків відомих нотних рукописних книг. Нотні знаки для зупинки, яких автор нарахував п'ять, також мають «особливий вид». Відзначаючи, що цей рукопис не молодший від відомих рукописних книг, дослідник вбачає схожіть нотних знаків в Кондакорі зі стародавніми грецькими нотними книгами і подає два знімки для порівняння [18, с. 3].

Кондакарний спів мав поспівкову структуру, де поспівки складалися із великих i малих кондакарних знаків. Поспівки кондакарного співу подібні до поспівок Стовпового розспіву, які діляться на початкові, середні і кінцеві. Кондакарні кінцеві поспівки повторюються на останніх рядках і часто-густо переходять із одного гласу в інший, закінчуючись знаком «омега». За своєю тривалістю поспівки були різні, як правило, до кожної з них входило від двох до шести малих кондкарних знаків. На один склад тексту поспівки припадало від 3 до 5 знаків нотопису, що підкреслювало мелізматичний характер кондакарного співу. Характерним принципом кондакарного співує варіаційне повторення, де при повторенні поспівки окремі знаки або групи знаків виконуються в різних варіантах [9].

Серед кондакарних поспівок Т. Владишевська виокремлює серединні та кінцеві. Це дає їй підставу порівняти їх із поспівками знаменного розспіву, серед яких також можна виділити початкові, середині та кінцеві. Про це зазначав дослідник В. Металлов ще наприкінці XIX ст. [13].

Аналізуючи кондакарний нотопис, дослідник С. Смоленський висловлював гіпотезу, що верхній рядок кондакарних знаків «мав експресивне значення і слугував поясненням для регента дати той чи інший відтінок виконання», тобто вказував на спосіб виконання, характер звучання, динамічні відтінки, ритм. А «нижній рядок відображав безпосередньо кондакарний розспів», а саме мелодію піснеспіву [15, с. 16]. Цю теорію пізніше розвинув I. Гарднер, який зазначав, що великі знаки можуть вказувати на різні способи співочої артикуляції і подачі звука. А деякі знаки верхнього рядка подібні з великими іпостазями (megalai upostaseis) - візантійськими знаками, що вказували на мелодичний малюнок, ритм або характер виконання [11, с. 306]. Його гіпотезу підтримує Т. Владишевська, яка зазначає, що великі кондакарні знаки можуть означати не тільки скорочену формулу мелодичного малюнку, а й спосіб та характер звучання знаків. Дослідниця припускає: в кондакарному співі міг використовуватися такий прийом як «ісон» - тривалі звуки. Їх тримали співці під час співу протопсалта, що було характерно для грецького богослужіння [9, с. 367].

Малі кондакарні знаки мали, на думку Т. Владишевської, різні функції, одні з них ділили мелодії на поспівки і рядки, це так звані заключні знаки, до яких відноситься «омега», другі знаки сприяли внутрішньоскладовій розспівності. Знак «крапка» виконував в кондакарній нотації синтаксичну і музичну функції. Він ставився в центрі, посередені рядка, ним розділялися поспівки між собою [10, с. 124]. Як називалися кондакарні знаки в період їхнього використання, на сьогодні невідомо, тому дослідник 
К. Флорос створюючи зведену таблицю кондакарних знаків на основі трьох Кондакорів (Благовещенського, Троїцького та Успенського) використав термінологію із палеовізантійської, медіовізантійської та руської Стовпової невменної нотації. У результаті виникли подвійні назви: апостроф і кома, оксія і стріла, варія і палка, петасте і крюк, класма і чашка, ставрос і криж, тінагма і паук, діпле і стаття, катабасма і зміїца. Зведена таблиця, складена К. Флоросом, має 40 малих і 76 великих кондакарних знаків [2].

М. Фіндейзен ставить під сумнів припущення дослідників про значення знамен верхніх рядків, відзначаючи, що вони можуть бути «не цілком вичерпним і точним». Для підтвердження своїх сумнівів дослідник вказує на Благовіщенський кондакар, де на п'яти сторінках налічується понад 60 різних знамен, тоді як знамен мотиву в нижніх рядках всього до сорока. Автор ставить запитання: «чи можна говорити про лише «експресивне»значення цих знамен?» [21].

Аналізуючи Благовіщенський кондакар М. Фіндейзен зазначає, що у верхніх рядках трапляються знаки аналогічні нижнім, іноді комбіновані (?), серед нижніх рядків зустрічаються надписані один над одним знамена $(?, ?)$. Усе це дає автору підстави припускати про наявність «дво- або трьохголосного співу», який виконувався освіченими півчими, переважно греками. Наприкінці свого дослідження автор припускає, що в XIV ст. кондакарні наспіви були перекладені звичайними знаменами, а потім «крюкові книги» відповідно на «київську квадратну нотацію» [21].

М. Успенський досліджуючи Благовіщенський кондакар приходить до висновку, що його першооснова є візантійською. Більш того, цей кондакар є свідоцтвом, що в Київській Русі насаджували візантійській спів у всіх його елементах, включно до прийомів виконавства. Порівнюючи кондакарну та стовпову невменну нотації, дослідник знаходить цілий ряд подібних музичних знаків. Це дає можливість стверджувати, що характер мелодій кондаків і кіноніків Благовіщенського кондакаря подібний до мелодій знаменного співу. Ця близкість, на думку М. Успенського, також підтверджується спільною системою восьмигласія, характерною для двох систем нотопису [20, с. 43]. Аналізуючи кондакарний нотопис, дослідник вказує на наявність знаків особливого виду, подібних до ієрогліфів, які розташовані в окремому рядку над невмами. М. Успенський, як свого часу М. Фіндейзен, також не підтримує думку С. Смоленського про те, що цими особливими знаками у верхньому рядку позначали експресію. М. Успенський стверджує, що це знаки жестикуляції, якими користувалися диригенти-доместики у зв'язку із недосконалістю нотації, коли потрібно було показати складний мелодійний зворот або хід голосу орнаментального характеру, це було неможливо записати звичайними невмами. Дослідник вказує на використання таких знаків у візантійських рукописах, для підтвердження своїх слів він згадує наукові праці Г. Римана та Е. Веллеша [6; 7]. Учений також посилається на свідчення Костянтина Порфирородного, який зазначає використання жестикуляції (хіромонії) під час візантійського придворного співу [1] .

Аналізуючи давні зображення та описи рук Іоанна Глікі, Кукузеліса, та Короніса М. Успенський припускає, що в давні часи диригенти-доместики пальцями вказували на певний інтервал під час виконання піснеспівів [20, с. 45]. На підтвердження своїх слів вчений зазначає, що в Благовіщенському кондакорі серед ієрогліфів є паралельні палички від двох до п’яти і ні разу шість, або більше шести. Ймовірно ці ієрогліфи 
пов'язані з використанням в хірономії п'яти пальців для позначення послідовності тонів у діапазоні квінти [20, с. 46].

Серед піснеспівів Благовіщенського кондакаря М. Успенський особливу увагу звертає на кондак хресту, записаний грецькою і слов'янською мовами. Музичні знаки обох текстів $є$ тотожними, за виключення кількох випадків, а саме в слов'янському тексті в кількох словах на один склад більше, аніж в оригіналі. Ця відмінність, на думку вченого, є помилкою через неуважність переписника. Як правило, над кожним складом грецького тексту розташовані невми. I коли кількість складів у грецьких словах не збігалася зі слов'янськими, тоді переписник збільшував їхню кількість за рахунок повторення голосних і напівголосних, таким чином розтягуючи слова. Це робилося для того, щоб кількість невм 3 грецького оригіналу була однакова і збігалася зі слов'янським перекладом. Така тотожність пов'язана з бажанням зберегти візантійські наспіви в слов'янських піснеспівах. Інакше не було б сенсу ділити руські двоскладові слова на дванадцяти- та сімнадцятискладові [20, с. 40-41].

Серед знаків кондакарного нотопису потрібно відзначити мартирії, які дуже подібні до палеовізантійських. У більшості випадків ці знаки трапляються на початку і наприкінці невеликих текстів. Мартирій у перекладі з грецької мови означає свідоцтво, підпис. У палеовізантійській та піздньовізантійській нотації початкові мартирії вказували на певний глас і початковий звук у піснеспіві. Наприкінці мартирії нагадували певний глас і вказували на кінцевий звук в мелодії піснеспіву. Дослідник Т. Владишевська, аналізуючи кондак св. Симіону Столпніку за різними кондакарями, робить висновок, що вони використовувалися по-різному. Так, в ТУ вона зазначає на різні види мартирій: рядкові і надрядкові. Це знаки у вигляді Ч або Цз двома крапками над буквою, мартирій IU $з$ крапками, Л з крапками і без крапок який трапляється у рядках і над рядками, та мартирій Г рядковий і надрядковий. У багатьох випадках мартирії закреслені або була спроба їх стерти, але вони все ж проглядаються. На їхньому місці в багатьох випадках стоїть крапка.

В Успенському кондакорі зустрічаються п'ять видів мартирій, в основному рядкових, за виключенням мартирія Г. Як було зазначено Ч або Цз двома крапками над буквою, мартирій IU з крапками, Л з крапками та мартирій Г рядковий і надрядковий. Більшість мартирій в Успенському кондакорі знаходиться на тих же місцях, що і в Друкарському статуті.

У Благовіщенському кондакорі перший аркуш дуже погано зберігся і тільки на другому аркіші кондака зустрічаємо один надрядковий мартирій Г.

У Троїцькому кондакорі всі мартирії рядкові за винятком мартирія Г в кінцевій поспівці. У результаті детального аналізу Т. Владишевська робить висновок, що мартирії в різних кондакорях мають певні особливості. Так, в одних мартирії використовуються як рядкові знаки, у других - надрядкові, а в третіх мають змішаний характер (рядкові і надрядкові). Успенський і Троїцький кондакорі дуже подібні між собою, що дає право стверджувати на їхню єдину редакцію. Потрібно зазначити, що система мартиріїв у кондакарній нотації на сьогодні недосліджена. Кондакарні мартирії мають свої особливості та закономірноті, які тільки частково подібні до візантійських. Нам невідоме значення мартиріїв на мелодичний малюнок піснеспівів, тому що кондакарний нотопис залишається не розшифрованим [9, с. 378-379]. 
Розквіт кондакарного співу в Київській Русі припадає на XI-XIII ст. Прийнято вважати, що, починаючи з XIV ст., цей спів поступово зникає з руської богослужбової практики. Так як на сьогодні нам невідомо про існування церковних книг, нотованих кондакарною нотацією, починаючи з XIV ст. Деякі дослідники пов'язують зникнення кондакарного нотопису зі зміною Студійського Статуту на Ієрусалимський, коли, відповідно, були замінені богослужбові книги. Але потрібно зазначити, що Студійський статут зберігався в Київській митрополії до половини XIV ст., з часом він починає поступатися ієрусалимському, але в деяких регіонах залишався в силі набагато довше, аж до початку XV ст. У деяких руських монастирях він діяв до XVIII ст. [17]. Дослідник C. Смоленський припускає, що спочатку зникає кондакарний нотопис, його заміняє стовповий невменний. Сам стиль співу продовжує використовуватися в церковному богослужінні, але з XVI ст., почав став називатися демественим [16].

Проти цієї гіпотези категорично виступає I. Гарднер, заявляючи, що стовповий невменний нотопис не здатний передати спосіб виконання кондакарного співу. Дослідник не бачить сенсу в переході від простої стовпової нотації до більш складної кондакарної, щоб потім знову повернутися до простої стовпової в одному і тому ж богослужбовому тексті [11. с. 314].

Головною причиною зникнення кондакарного співу В. Металлов вважає монголотатарські напади на руські землі в 1237-1238 pp., у результаті чого були розорені культурні центри (Київ, Володимир-на-Клязмі та ін.), а відповідно був значний брак освічених півчих [14, с. 234].

У свою чергу дослідник М. Успенський висловлює іншу гіпотезу - зникненню кондакарного співу послужила непримеренна боротьба між грекофільською та національно-руською партією серед православного кліру. У той час, коли стовповий спів з часом русифікувався, а кондакарний залишався лише візантійським, особливо в манері виконання, відповідно сприймався руськими півчими як іноземний і все рідше використовувався. Протягом XIV ст. він взагалі вийшов із вжитку, втративши характерні особливості, він злився зі стовповим співом [19].

I. Гарднер частково підтримує думку М. Успенського, відзначаючи, що в цей період тісні взаємовідносини між Візантією та Києвом були призупинені, так як Київська Русь потерпала від набігів монголо-татарів, а Константинополь був захоплений хрестоносцями. Однією з головних причин, на думку I. Гарднера, був Собор 1274 p. на якому мали відбутися реформи в богослужбовому співі. Хоча, як зазначає дослідник, документальних свідоцтв про таку реформу не збереглося [11, с. 317, 319]. Наступною причиною зникнення кондакарного нотопису $є$ поширення канонуз одночасною втратою провідного значення кондака під час Утрені. Кондак поступово був змінений простими ірмологійними наспівами, а стовповий спів зайняв центральне місце в церковному богослужінні. Це, на думку I. Гарднера, призвело до поступового зникнення кондакарного нотопису [11, с. 319]. І останнє, як вважає дослідник, кондакарний спів після свого розквіту почав занепадати, був втрачений смак до естетичного розуміння вишуканості, а саме змінилися уподобання [11, с. 320]. На нашу думку, говорити про вплив модних віянь на православне богослужіння XIII-XIV ст., яке було і $є$ до сьогодні ортодоксальним, досить малоймовірно і не може бути причиною відмови від кондакарного співу та нотопису. 
У 1953 р. Р. Палікарова-Вердель висловлює гіпотезу, що прототипом кондакарного нотопису є одним із видів палеовізантійської нотації, а саме «шартрська», цей фрагмент зберігається в муніципальній бібліотеці міста Шартра (Codex Chartres, 1754). Це достатньо відомий рукопис Стихираря Lavra ?.67, який датується приблизно X-ХІ ст. [5].

В останній час все більше дослідників вбачають зв'язок шартрської нотації із кондакарною. Признаючи подібність шартських знаків до руських кондакарних, Т. Владишевська відзначає, що збіг між ними становить не більше 50\%, а загальний вигляд і будова двох нотацій різна [9]. На думку Т. Владишевської, шартрська нотація більш подібна до знаменної (невматичної), аніж до кондакарної. У своїх твердженнях дослідниця посилається на Афонські рукописи Х ст., написані шартрською нотацією $[9$, с. 368$]$.

Європейські та американські вчені активно намагаються розшифрувати руський кондакарний нотопис при цьому проводячи паралелі із візантійськими прототипами i широко використовуючи метод компаративного дослідження джерел. Так, зв'язок між візантійським Асматіконом і руськими Кондакарями встановили медієвісти Кеннет Леві та Костянтин Флорос. Ними були проаналізовані незмінні піснеспіви церковної служби: кіноніки (причастні вірші), іпакої і тропарі [2; 3]. Цей спосіб не привів до позитивного результату, оскільки дослідники використовували медіовізантійські рупописи як паралельний текст. І. Гарднер ставиться досить скептично до спроб К. Флороса, стверджуючи, що його розшифровки можна віднести тільки до читання грецької нотації. Цей переклад не може передати відтінки та характер виконання мелодій. Спів людського голосу не може передати жоден музичний інструмент [11, с. 302]. Дослідник I. Гарднер зазначає, що на сьогодні невідомо, чи у всіх кондакарних рукописах однаковий тип нотопису, чи існувало кілька його типів. Також потрібно відзначити, що в грецькій нотації відсутні великі знаки і послідовність співочих знаків відмінна від послідовностей, які $\epsilon$ в руських Кондакорях. Тому грецький нотопис, на думку дослідника, не може бути тотожним зі слов'янським ні в мелодичному, ні в тональному плані. Це зовсім різні системи нотації та різні види церковного співу [11, с. 302-303].

Вчений І. Гарднер висловлює думку, що намагання розшифрувати кондакарний нотопис, це не тільки визначити «висоту звуку, його тривалість і послідовність тонів», а й «визначення тембрів і характеру співочої артикуляції». Ця проблема здається I. Гарднеру нерозв'язною $[11$, с. 306]. Але багато дослідників не втрачають надії наблизитись і максимально розшифрувати кондакарний нотопис. Така можливість, на нашу думку, існує, при більш грунтовному дослідженні старовинних рукописів та використанні нових технологій, які можуть суттєвого допомогти науковцям. Також не треба виключати можливості знаходження невідомих у науці рукописів з кондакарною нотацією, що можуть дати ключ до розшифрування відомих кондакарів.

\section{Jimepamypa:}

1. Constantini Porphyrogeniti imperatoris De ceremoniis aulae Byzantinae libri duo Graece et Latine / imperatoris Constantini Porphyrogeniti. - Impensis Ed. Weberi, 1829-1830. 2. Floros C. Universale Neumenkunde. Band 1: Entzifferung der altesten byzantinischen Neumenschriften und der altslavischen sematischen Notation / C.Floros. - Barenreiter, Kassel, 1970. 3. Floros C. 
Die Entzifferung der Kondacarien-Notation/C. Floros. - в кн.: Music des Ostens, Bd 3-4, Kassel, 1965-1967. 4. Hoeg C. The Oldest Slavonic Tradition of Byzantine Music Proceedings of the British Academy / C.Hoeg. -V. 39. Jan 1953. 5. Palikarova-Verdeil R. La musique byzantine chez les Bulgares et les Russes (du IX au XIV siecle) / R.Palikarova-Verdeil.-MMB. Subsidia. Copenh., 1953. - Vol. 3. 6. Riemann H. Die Byzantinische Notenschrift in 10 bis 15 Jahrhundert/ H. Riemann. - Leipzig. 1909. 7. Wellesz E. Byzantinische Kirchenmusik / E. Wellesz. - Breslau, 1927. 8. Владышевская Т. Ф. Кондакарь типографского устава и музыкальная культура древней Руси XI - XII веков співу [Электронный ресурс]. -Режим доступа: http:// www.portal-slovo.ru/art/36017.php. - Название с экрана. 9. Владышевская T. Ф. Музыкальная культура Древней Руси / Т. Ф.Владышевская.-Москва : Знак, 2006. - 472 с. 10. Владышевская T. Ф. Типографский Устав и музыкальная культура Древней Руси XI-XII веков / T. Ф.Владышевская. - Москва, 2006. - Т. III. - С. 111-204. 11. Гарднер И. Богослужебное пение русской православной церкви / И. Гарднер. -Москва, 2004. - Т. 1. - 495 с. 12. Еволючія знаменного розспіву як основної форми украӥнського богослужбового співу [Електронний pecypc]. - Режим доступу: http://ukrspiritmuz.net.ua/pages/5_2.html. - Назва з екрана. 13. Металлов В. М. Азбука крюкового пения / В. М. Металлов. - Москва, 1899. - 130 с. 14. Металлов В. М. Богослужебное пение Русской Церкви в период домонгольский по историческим, археологическим и палеографическим данным / В. М. Металлов. - Москва, 1912. - T. ХIV. - 349 с. 15. Смоленский С. В. О древнерусских певческих нотациях / С. В. Смоленский. - ОЛДП, 1901. - 120 с. 16. Смоленский С. В. Несколько новых данных о так называемом кондакарном знамени / С. В. Смоленский. - Санкт-Петербург, 1913. № 44. 17. Студійський_устав [Електронний ресурс] Режим доступу: https:// uk.wikipedia.org/wiki. - Назва з екрана. 18. Ундольский В. М. Замечанія для исторіи иерковнаго пенія в Россіи / В. М. Ундольский. - Окружные жители Балтийского моря, то есть Леты и Славяне. - Москва, 1846. - № 3. - 111 с. 19. Успенский Н. Византийское пение в Киевской Руси / H. Успенский. - Akten des IX. Internationalen Byzantinisten-Kongresses, Munchen 1958. Munchen, 1960. - S. 653. 20. Успенский Н. Древне-русское певческое искусство / Н. Успенский. - Москва, 1965. - 214 с. 21. Финдейзен Н. Ф.Очерки по истории музыки в России с древнейших времен до конияа ХVIII века / Н. Ф.Финдейзен-Москва, 1928. - Bып. 1. $103 \mathrm{c}$. 